\title{
LICENCJONOWANIE PRZYMUSOWE W PRAWIE UNIJNYM ORAZ UMOWACH MIĘDZYNARODOWYCH WIĄŻĄCYCH RZECZPOSPOLITĄ POLSKĄ
}

\section{WSTĘP}

O systemie licencjonowania przymusowego wiadomo niezbyt wiele. W Polsce nie zajmuje on szczególnego miejsca w doktrynie, gdyż nie stosuje się go w praktyce. Pomimo szczegółowego uregulowania instytucji licencji przymusowej w Prawie własności przemysłowej z 30 czerwca 2000 r. ${ }^{1}$, do tej pory nie zastosowano przepisów odnoszących się do opisywanej problematyki. Urząd Patentowy Rzeczypospolitej Polskiej udzielił ostatniej licencji przymusowej w 1990 r., kiedy to wydano zezwolenie na korzystanie z rozwiązania dotyczącego urządzenia do gaszenia ognia, przeznaczonego zwłaszcza dla maszyn górniczych ${ }^{2}$. Wówczas nie obowiązywała jednak ustawa, która posługujemy się dzisiaj.

Licencjonowanie przymusowe jest jednak bardzo ważną i obiecująca instytucja prawna, ponieważ dotyka znaczące dziedziny życia, takie jak zdrowie publiczne. Instytucja licencji przymusowej istnieje w prawie międzynarodowym oraz prawach wielu państw od ponad 100 lat $^{3}$, ale w ostatnich latach stała się przedmiotem szerokich dyskusji na świecie. Nie tylko dlatego, że wciąż wzbudza wiele kontrowersji ${ }^{4}$, lecz także w związku z postępem globa-

\footnotetext{
1 Tekst jedn.: Dz. U. 2013, poz. 1410, art. 82-88.

${ }^{2}$ Decyzja Urzędu Patentowego RP działającego w trybie postępowania spornego z 17 sierpnia 1990 r. w sprawie Sp. 66/90, „Wiadomości Urzędu Patentowego” 1991, nr 3, s. 290.

${ }^{3}$ Instytucja licencji przymusowej funkcjonowała w Polsce już w ustawie z 5 lutego $1924 \mathrm{r}$. o ochronie wynalazków, wzorów i znaków towarowych (Dz. U. 1924, Nr 31, poz. 306). Nawiązywała do niej również Konwencja związkowa paryska z 20 marca 1883 r. o ochronie własności przemysłowej.

${ }^{4}$ W 2012 r. przyznano pierwszą licencję przymusową w Indiach na produkt farmaceutyczny na rzecz Natco Pharma Limited (indyjska spółka farmaceutyczna). Przedmiotem licencji był patent nr 215758 należący do Bayer Corporation. W tym przypadku decyzja o udzieleniu licencji przymusowej wywołała dyskusję dotyczącą nadużywania systemu licencjonowania przymusowego przez państwa, które uważane są za najszybciej rozwijające się. Argumentowano wówczas, że udzielenie opisywanej licencji mogło mieć na celu jedynie zwiększenie konkurencyjności indyjskiego rynku farmaceutycznego. Z kolei w Unii Europejskiej Komisja Europejska wszczęła w 2007 r. procedurę badawczą (sygn. 2007/C 47/11) w związku ze skargą spółki Philips Corporation na decyzję chińskiego Urzędu Patentowego (IPO) o udzieleniu licencji przymusowej na pięć patentów
} 
lizacji i pojawianiem się nowych technologii, zastosowań czy metod. Według raportu z 3 listopada 2014 r. przygotowanego przez Stały Komitet Światowej Organizacji Własności Intelektualnej ds. Prawa Patentowego (WIPO; ang. Standing Committee on the Law of Patents - SCP) w sumie 87 państw członkowskich uznaje $\mathrm{w}$ swoich systemach prawnych licencjonowanie przymuso$\mathrm{we}^{5}$. Stanowi to ponad połowę wszystkich członków WIPO. Niemniej jednak licencji przymusowych udziela się niezmiernie rzadko, gdyż związane są one z wystapieniem szczególnych okoliczności. Umiejętność wykorzystania szans, jakie niesie za sobą system licencjonowania przymusowego, może jednak pozytywnie wpłynać na rynek. Kanada jest tego świetnym przykładem. W latach 1969-1992 udzielono tam aż 613 licencji przymusowych na produkty farmaceutyczne, co spowodowało znaczny wzrost wartości rynku leków generycznych (generyków) ${ }^{6}$.

Polski ustawodawca w sposób szczegółowy uregulował licencjonowanie przymusowe. Regulacje, które znajdują się w polskich przepisach prawnych, muszą być jednak kompatybilne zarówno z prawem unijnym, jak i prawem międzynarodowym właściwym w opisywanym zakresie. Niniejszy artykuł ma na celu przybliżenie tych regulacji prawnych wynikających z prawa unijnego, a także z umów, konwencji czy porozumień międzynarodowych wiążących Polskę, które w sposób pośredni lub bezpośredni odnoszą się do kwestii licencjonowania przymusowego oraz miały wpływ na zakreślenie ram prawnych tej instytucji w polskim ustawodawstwie.

\section{AKT SZTOKHOLMSKI ZMIENIAJĄCY KONWENCJĘ PARYSKĄ O OCHRONIE WŁASNOŚCI PRZEMYSŁOWEJ}

Rada Państwa Polskiej Rzeczypospolitej Ludowej 5 grudnia 1974 r. ratyfikowała Akt sztokholmski zmieniający Konwencję paryską o ochronie własności przemysłowej z 20 marca 1883 r. zmienioną w Brukseli-14 grudnia 1900 r., w Waszyngtonie - 2 czerwca 1911 r., w Hadze - 6 listopada 1925 r., w Londynie - 2 czerwca 1934 r., w Lizbonie - 31 października 1958 r., sporządzony w Sztokholmie - 14 lipca 1967 r. ${ }^{7}$ Akt wszedł w życie w marcu 1975 r. Polska

\footnotetext{
dotyczących zapisywalnych dysków kompaktowych należących do spółki Philips Electronics na rzecz chińskiego producenta płyt CD-R, spółki Gigastorage Corporation. Według spółki Philips Corporation decyzję o udzieleniu wymienionej licencji podjęto na podstawie przepisów niezgodnych z Porozumieniem TRIPS, którego stroną jest Chińska Republika Ludowa. Komisja Europejska podzieliła zdanie skarżącej spółki, stwierdzając, że przepisy chińskie niekorzystnie wpływaja na handel i naruszają interesy całej Wspólnoty.

${ }_{5}^{5}$ Pełen tekst raportu dostępny na: http://www.wipo.int/edocs/mdocs/scp/en/scp_21/scp_21_4_ rev.pdf [dostęp: 10.12.2016].

${ }^{6}$ S. Chaudhuri, TRIPS and Changes in Pharmaceutical Patent Regime in India, Working Paper 2005, s. 22-24 (http://www.who.int/hiv/amds/IDA_India-Patent-amendments-Sudip.pdf?ua=1 [dostęp: 10.12.2016]).

7 Dz. U. 1975, Nr 9, poz. 51 (dalej jako: Akt sztokholmski).
} 
jest stroną Konwencji paryskiej już od 10 listopada 1919 r. ${ }^{8}$, a sam Akt sztokholmski obecnie obowiązuje 165 państw $^{9}$.

Zgodnie z art. 5A ust. 2 Aktu sztokholmskiego każde państwo będące członkiem Związku Ochrony Własności Przemysłowej może przewidzieć w swoim ustawodawstwie możliwość udzielania licencji przymusowych, aby zapobiegać nadużyciom, jakie mogłyby wyniknąć z wykonywania prawa wyłącznego, przyznanego przez udzielenie patentu (np. na skutek zaniechania jego stosowania). Państwa członkowskie nie są zatem zobligowane do wprowadzenia systemu licencjonowania przymusowego w swoich ustawodawstwach. Niemniej jeśli ustawodawca danego państwa podejmuje się regulacji tego systemu, musi on dostosować krajowe przepisy do warunków opisanych w dalszych ustępach art. 5A Aktu sztokholmskiego. Wynika z nich m.in., że wygaśnięcie patentu możliwe jest tylko w przypadku, gdyby udzielenie licencji przymusowej nie wystarczyło do zapobieżenia nadużyciom, przy czym nie jest możliwe wszczęcie żadnego postępowania o wygaśnięcie lub cofnięcie patentu przed upływem dwóch lat od udzielenia pierwszej licencji przymusowej. Ponadto nie można wnosić o udzielenie licencji przymusowej z powodu zaniechania lub niewystarczającego stosowania patentu przed upływem czterech lat od dokonania zgłoszenia o udzielenie patentu lub trzech lat od udzielenia patentu (należy stosować termin, który upływa najpóźniej). Udzielenie licencji przymusowej spotka się z odmową również wtedy, gdy uprawniony z patentu usprawiedliwi swa bezczynność w jego stosowaniu słusznymi przyczynami. Dalej z art. 5A Aktu sztokholmskiego wynika, że licencja przymusowa musi mieć charakter niewyłączny i co do zasady nieprzenoszalny. Licencję tego rodzaju można przenieść jedynie z częścią przedsiębiorstwa stosującego tę licencję (nawet w formie udzielenia sublicencji). Opisane powyżej postanowienia (warunki), z zastrzeżeniem niezbędnych zmian, stosuje się również do wzorów użytkowych.

Konwencja paryska w brzmieniu Aktu sztokholmskiego nie nakłada na państwa strony obowiązku wprowadzenia systemu licencjonowania przymusowego w swoich ustawodawstwach. Niemniej jednak reguluje warunki licencjonowania przymusowego i obliguje państwa do ich przestrzegania w sytuacji, gdy w państwach tych funkcjonuje opisywana instytucja prawna.

\section{POROZUMIENIE W SPRAWIE HANDLOWYCH ASPEKTÓW PRAW WKASNOŚCI INTELEKTUALNEJ}

Porozumienie w sprawie handlowych aspektów praw własności intelektualnej (ang. Agreement on Trade-Related Aspects of Intellectual Property Rights - TRIPS) ${ }^{10}$ zawarto w 1994 r. po kolejnej rundzie liberalizacyjnej

\footnotetext{
${ }^{8}$ Prezydent Ignacy Mościcki ratyfikował Konwencję paryską dopiero w lipcu 1931 r.

9 Ostatnim państwem, które przyjęło Konwencję paryską z brzmieniu Aktu sztokholmskiego, jest Kuwejt (2 grudnia 2014 r.); pełna lista państw, które przyjęły Konwencję paryską dostępna na: http://www.wipo.int/export/sites/www/treaties/en/documents/pdf/paris.pdf [dostęp: 29.02.2016].

10 Dz. U. 1996, Nr 32, poz. 143.
} 
GATT $^{11}$ (tzw. runda urugwajska). Stanowi ono załącznik do porozumienia w sprawie utworzenia Swiatowej Organizacji Handlu (ang. World Trade Organization - WTO). Polska ratyfikowała porozumienie w sprawie utworzenia WTO już 31 lipca 1995 r., jako jedno z państw współzałożycieli tej organizacji. Obecnie członkami WTO sa 164 państwa, a status obserwatorów posiada 20 państw $^{12}$.

Porozumienie TRIPS w sposób szczegółowy reguluje kwestię licencjonowania przymusowego, choć nie jest w nim używany zwrot „licencja przymusowa”. Zgodnie z jego art. 30 państwa członkowskie WTO moga dokonać ograniczonych wyłączeń od praw wyłącznych przyznanych patentem, pod warunkiem że takie wyłączenia nie są bezzasadnie sprzeczne z normalnym wykorzystaniem patentu i nie naruszaja prawnie uzasadnionych interesów właściciela patentu oraz biora pod uwagę prawnie uzasadnione interesy stron trzecich. Jako normalne wykorzystanie patentu można rozumieć takie jego wykorzystywanie przez uprawnionego, które nie jest nadużywaniem patentu, tj. wyklucza stosowanie takich form konkurencji, które mogą negatywnie wpłynąć na rynek. Jednym z głównych dopuszczalnych ograniczonych wyłączeń od praw wyłącznych przyznanych patentem jest na pewno licencja przymusowa.

W przypadku gdy ustawodawstwo państwa członkowskiego zezwala na inne użycie przedmiotu patentu bez upoważnienia posiadacza praw (np. licencja przymusowa), musi ono odpowiadać warunkom enumeratywnie wymienionym $\mathrm{w}$ art. 31 TRIPS:

1. Upoważnienie do takiego użycia jest rozpatrywane z każdej indywidualnej sprawie co do zasadności.

2. Użycie takie jest dozwolone jedynie wówczas, gdy strona trzecia poczyniła wcześniej starania, aby uzyskać zezwolenie od uprawnionego na rozsądnych warunkach handlowych, jednakże starania te nie przyniosły rezultatu w rozsądnym terminie. Od tej zasady przewidziano wyjątki. Państwo członkowskie może odstapić od opisanego wymogu w przypadku zagrożenia bezpieczeństwa narodowego lub wystapienia innych okoliczności wymagających działań o nadzwyczajnej pilności (wówczas uprawniony będzie powiadomiony o udzieleniu licencji przymusowej na jego patent w możliwie najkrótszym czasie) lub w przypadku publicznego użycia patentu dla celów niehandlowych (wówczas uprawniony będzie niezwłocznie informowany, jeśli rząd lub kontrahent bez przeprowadzenia poszukiwań patentowych wie lub ma wszelkie dajace się udowodnić dane, by wiedzieć, że ważny patent jest lub będzie używany przez rząd lub dla jego celów).

3. Zakres i okres takiego innego używania jest ograniczony do celu, dla którego zostało wydane upoważnienie. W przypadku technologii półprzewodnikowej dotyczy to wyłącznie jawnego używania w celach niehandlowych lub dla przeciwdziałania praktykom uznanym w trybie postępowania sądowego lub administracyjnego za antykonkurencyjne.

${ }^{11}$ Układ Ogólny w sprawie Taryf Celnych i Handlu (ang. General Agreement on Tariffs and Trade) podpisany w Genewie 30 października $1947 \mathrm{r}$.

${ }^{12}$ Lista państw członkowskich dostępna na: https://www.wto.org/english/thewto_e/whatis_e/ tif_e/org6_e.htm [dostęp: 10.12.2016]. 
4. Używanie takie jest niewyłączne oraz co do zasady nieprzenoszalne. Wyjątkiem od zasady nieprzenoszalności jest możliwość przeniesienia owego innego używania (np. przeniesienie licencji przymusowej) wraz z częścią przedsiębiorstwa, która korzysta z takiego użycia.

5. Zezwolenie na takie używanie może zostać wydane głównie w celu zaopatrywania rynku wewnętrznego państwa członkowskiego, które wydaje upoważnienie do używania patentu.

6. Zezwolenie do takiego używania podlega wygaśnięciu z zachowaniem odpowiedniej ochrony prawnie uzasadnionych interesów osób upoważnionych, jeśli okoliczności, które doprowadziły do jego wydania, ustaną i jest mało prawdopodobne, aby miały się powtórzyć. Na podstawie umotywowanego wniosku właściwy organ będzie uprawniony do sprawdzenia, czy takie okoliczności nadal istnieja.

7. Uprawnionemu z patentu musi zostać wypłacone odpowiednie do okoliczności sprawy wynagrodzenie na podstawie wartości ekonomicznej takiego upoważnienia.

8. Prawomocność zezwolenia na takie używanie, jak i decyzja dotycząca wynagrodzenia należnego w związku z takim używaniem podlega kontroli sądowej lub innej niezależnej kontroli ze strony odrębnego organu wyższej władzy w danym państwie członkowskim.

9. Państwa członkowskie nie są zobowiązane do stosowania dwóch z wyżej wymienionych w pkt 2 oraz 5 postanowień, jeżeli takie inne używanie jest dozwolone dla przeciwdziałania praktykom uznanym w drodze postępowania sądowego lub administracyjnego za antykonkurencyjne. W takim przypadku potrzeba przeciwdziałania praktykom antykonkurencyjnym może być wzięta pod uwagę również przy określaniu sumy wynagrodzenia należnemu uprawnionemu, jak również właściwe organy będą miały prawo odmówić odwołania zezwolenia na takie używanie, gdy istnieje domniemanie ponownego wystąpienia warunków, które doprowadziły do jego wydania.

10. Istnieja trzy dodatkowe warunki w przypadku, gdy upoważnienie do takiego używania zezwala na wykorzystywanie patentu zależnego, który nie może być stosowany bez naruszania innego patentu wcześniejszego. Po pierwsze, wynalazek zastrzeżony w patencie zależnym stanowi istotny postęp techniczny o poważnym znaczeniu gospodarczym w porównaniu $\mathrm{z}$ wynalazkiem zastrzeżonym $\mathrm{w}$ patencie wcześniejszym. Po drugie, uprawniony z patentu wcześniejszego będzie miał prawo do licencji wzajemnej, na rozsądnych warunkach, dotyczącej używania wynalazku zastrzeżonego w patencie zależnym. Po trzecie, używanie patentu wcześniejszego nie może zostać przeniesione, z wyjątkiem możliwości przeniesienia wraz z patentem zależnym.

Nie sposób w tym miejscu nie nawiązać do Protokołu zmieniającego porozumienie TRIPS, sporządzonego w Genewie 6 grudnia 2005 r. ${ }^{13}$ Cztery lata wcześniej, 14 listopada 2001 r., przyjęto Deklarację w sprawie porozumienia TRIPS i zdrowia publicznego (tzw. Deklarację dauhańska - ang. Doha Declaration on TRIPS and Public Health) ${ }^{14}$. Zgodnie z jej ust. 6 Rada ds. TRIPS

13 Dz. Urz. UE L 311 z 29 listopada 2007 r., s. 35.

14 Tekst Deklaracji dauhańskiej dostępny na: www.wto.org/english/thewto_e/minist_e/ min01_e/mindecl_trips_e.htm [dostęp: 10.12.2016]. 
miała znaleźć rozwiązanie problemu braku zdolności produkcyjnych w sektorze farmaceutycznym w państwach członkowskich WTO, które chciałyby korzystać z systemu licencjonowania przymusowego zgodnie z porozumieniem TRIPS. W związku z tym zobowiązaniem Rada Generalna WTO przyjęła 30 sierpnia 2003 r. decyzję tymczasowa ${ }^{15}$ dotycząca opisanego problemu. Decyzja ta zmieniła się w stałą zmianę porozumienia TRIPS z dniem 6 grudnia $2005 \mathrm{r}$. (Protokół zmieniający porozumienie TRIPS ${ }^{16}$.

Zgodnie z Protokołem do TRIPS ma zostać dodany art. 31bis oraz jeden załącznik (po art. 73 porozumienia). Dodatkowy artykuł reguluje kwestie przyznawania licencji przymusowych $\mathrm{w}$ zakresie niezbędnym do produkcji produktów farmaceutycznych i ich wywozu przez eksportujące państwa strony porozumienia TRIPS do państw importujących. Państwami eksportującymi sa te państwa członkowskie WTO, które korzystaja z systemu licencji przymusowych w celu wytwarzania produktów farmaceutycznych i ich wywozu. Państwami importującymi sa natomiast te państwa członkowskie WTO, które powiadomiły Radę ds. TRIPS o zamiarze korzystania w charakterze importera $\mathrm{z}$ systemu licencjonowania przymusowego $\mathrm{w}$ pełni lub w ograniczonym zakresie. Zgodnie z dodanym artykułem postanowienia art. 31 lit. f TRIPS (wydanie zezwolenia na używanie patentu uprawnionego bez jego zgody będzie miało miejsce w celu zaopatrywania rynku wewnętrznego państwa członkowskiego, które udziela takiego zezwolenia) nie mają w opisanym przypadku zastosowania.

W załączniku dodanym po art. 73 TRIPS zawarte sa warunki wydawania zezwoleń na używanie patentu bez zgody uprawnionego na produkty farmaceutyczne. Podkreślona w nim również została potrzeba wspierania transferu technologii i rozwoju możliwości w sektorze farmaceutycznym. Znaleźć w nim można także zobowiązanie Rady ds. TRIPS do dokonywania corocznych przeglądów funkcjonowania systemu licencjonowania przymusowego w zakresie produktów farmaceutycznych dla państw importujących wraz z koniecznościa składania sprawozdania na temat działania tego systemu Radzie Ogólnej WTO.

Utworzenie Protokołu zmieniającego TRIPS było odpowiedzią na problemy związane ze zdrowiem publicznym, szczególnie w krajach słabo rozwiniętych. Przedstawiciele wielu z nich wskazywali na niemożność skutecznego korzystania z systemu licencjonowania przymusowego w dotychczasowym brzmieniu, gdyż na ich rynkach nie ma mocy produkcyjnych (specjalistów, sprzętu, fabryk, technologii), które zagwarantowałyby możliwość wytworzenia danego produktu farmaceutycznego na podstawie licencji przymusowej. Wprowadzone protokołem zmiany ułatwiłyby krajom słabo rozwiniętym importowanie tańszych leków generycznych (generyki) wytwarzanych na podstawie licencji przymusowej w innych krajach. Niemniej jednak ze względu na postanowienia art. X ust. 3 Porozumienia w sprawie utworzenia WTO w zw. z pkt 4 Protokołu

${ }_{15}$ Tekst decyzji tymczasowej dostępny na: www.wto.org/english/tratop_e/trips_e/implem_ para6_e.htm [dostęp: 10.12.2016].

${ }^{16}$ Tekst Protokołu dostępny na: www.wto.org/english/tratop_e/trips_e/wtl641_e.htm [dostęp: 10.12.2016]. 
zmieniającego TRIPS (stanowi on, że poprawki do postanowień porozumienia w sprawie utworzenia WTO lub do wielostronnych porozumień handlowych zawartych w załącznikach wejdą w życie dla przyjmujących je członków po ich uprzednim przyjęciu przez dwie trzecie wszystkich członków WTO) poprawki, o których mowa wyżej, nie weszły do tej pory w życie. Jak już wskazano, liczba państw członkowskich WTO wynosi obecnie 164. Protokół przyjęło do tej pory 79 państw i 1 organizacja międzynarodowa (Unia Europejska) ${ }^{17}$.

Unia Europejska przyjęła w imieniu Wspólnoty Europejskiej Protokół zmieniajacy porozumienie TRIPS decyzją Rady Unii Europejskiej z 19 listopada 2007 r. ${ }^{18} \mathrm{~W}$ negocjacjach dotyczacych Protokołu brali udział przedstawiciele Komisji Europejskiej, którzy złożyli wniosek o przyjęcie proponowanej przez Radę Generalną WTO zmiany TRIPS. Parlament Europejski przyją ten wniosek 24 października 2007 r., w związku z czym Rada Unii Europejskiej wydała decyzję o przyjęciu Protokołu zmieniającego TRIPS w imieniu wszystkich państw członkowskich UE. Artykuł 3 wymienionej decyzji stanowi bowiem, że w momencie wejścia w życie Protokołu zmieniającego TRIPS będzie on wiążący dla wszystkich państw członkowskich Unii Europejskiej.

\section{TRAKTAT O STOSUNKACH HANDLOWYCH I GOSPODARCZYCH MIĘDZY RZECZĄPOSPOLITĄ POLSKĄ A STANAMI ZJEDNOCZONYMI AMERYKI ${ }^{19}$}

Traktat, o którym mowa w tytule niniejszego punktu, został sporządzony w Waszyngtonie 21 marca 1990 r. Polska była wówczas na początku swojej drogi jako wolne państwo, nie będąc członkiem WTO czy Unii Europejskiej. Stany Zjednoczone przed rozpoczęciem współpracy z polskim państwem chciały w sposób kompleksowy zadbać o swoje interesy. W związku z tym przyjęto szereg regulacji, w tym dotyczących licencjonowania przymusowego.

Aneks pierwszy traktatu stanowi, że umawiające się strony mogą ograniczyć wyłączne prawa uprawnionego z patentu jedynie przez zastosowanie instytucji niewyłącznej licencji przymusowej. Możliwe jest przyznanie takiej licencji jedynie w celu przeciwdziałania nadużyciom wyłącznych praw wynikających z patentu, jak np. naruszanie praw chroniących konkurencję stwierdzone przez sąd lub ze względu na ogłoszone zagrożenie narodowe. W sytuacji, w której doszłoby do wydania tego rodzaju licencji, uprawnionemu z patentu przysługuje przyznanie stosownego wynagrodzenia współmiernego do wartości rynkowej zwykłej licencji. Decyzja właściwego organu o wydaniu licencji przymusowej musi ponadto podlegać odpowiedniej kontroli sądowej.

17 Ostatnim państwem, które przyjęło Protokół, jest Dominika - 28 listopada 2016 r.; pełna lista państw, które przyjęły Protokół, dostępna na: https://www.wto.org/english/news_e/news16_e/ trip_23feb16_e.htm [dostęp: 10.12.2016].

18 Dz. Urz. UE L 311 z 29 listopada 2007 r., s. 35.

19 Dz. U. 1994, Nr 97, poz. 467. 


\section{UKŁAD O WSPÓŁPRACY PATENTOWEJ}

Układ o współpracy patentowej sporządzono w Waszyngtonie 19 czerwca 1970 r., poprawiono 2 października 1979 r. i zmieniono 3 lutego 1984 r. ${ }^{20}$ Obowiązuje on w Polsce od 1991 r. Nie znajdują się w nim co prawda szczegółowe regulacje dotyczace problematyki licencjonowania przymusowego, jednakże art. 27 ust. 8 Układu stanowi, że żadne z jego postanowień nie zmierza do ograniczenia swobody umawiajaccych się państw w stosowaniu środków, jakie uznaja one za niezbędne dla ochrony swego bezpieczeństwa. Każde państwo będące strona Układu może zatem przewidywać w swoim ustawodawstwie taki środek bezpieczeństwa, jak licencjonowanie przymusowe.

\section{PRAWO UNIJNE}

Żaden unijny akt prawny nie nakłada na państwa członkowskie Unii Europejskiej obowiązku wprowadzenia w swoim ustawodawstwie licencjonowania przymusowego, niemniej jednak istnieja w unijnym systemie prawnym takie regulacje, które muszą znaleźć bezpośrednie stosowanie w każdym z państw członkowskich UE.

\section{Rozporządzenie (WE) nr 816/2006 Parlamentu Europejskiego i Rady} z 17 maja 2006 r. w sprawie udzielania licencji przymusowych na patenty dotyczące wytwarzania produktów farmaceutycznych przeznaczonych na wywóz do krajów, w których występują problemy związane ze zdrowiem publicznym ${ }^{21}$

We wstępie rozporządzenia można przeczytać, że ma ono stanowić część szerszych działań podejmowanych nie tylko w skali europejskiej, ale również międzynarodowej w celu rozwiązania problemów dotyczacych zdrowia publicznego doświadczanych przez kraje najsłabiej rozwinięte oraz kraje rozwijające się, w szczególności w celu poprawy dostępu do bezpiecznych, skutecznych i wysoko jakościowych leków po przystępnych cenach. W związku z tym, że celem systemu licencjonowania przymusowego jest podjęcie działań służących rozwiązaniu problemów dotyczących zdrowia publicznego, powinien być on wykorzystywany przez państwa w dobrej wierze, a nie do realizacji celów polityki przemysłowej lub handlowej. Celem samego rozporządzenia jest stworzenie takich ram prawnych, które byłyby bezpieczne i zniechęcałyby do wszczynania sporów prawnych.

Zgodnie z rozporządzeniem państwami kwalifikującymi się do przywozu produktów farmaceutycznych są kraje najsłabiej rozwinięte (zgodnie z norma przyjmowaną przez Organizację Narodów Zjednoczonych), państwa członkowskie WTO, które powiadomiły Radę ds. TRIPS o zamiarze korzystania z systemu licencjonowania przymusowego w całości lub w ograniczonym zakre-

20 Dz. U. 1991, Nr 70, poz. 303.

21 Dz. Urz. UE L 157 z 9 czerwca 2006 r., s. 1. 
sie jako importerzy, jak również każde inne państwo nieczłonkowskie WTO uwzględnione w wykazie krajów o niskich dochodach Komisji Pomocy Rozwojowej Organizacji Współpracy Gospodarczej i Rozwoju (ang. Organization for Economic Co-operation and Development - OECD), tzn. państw, których PKB per capita wynosi poniżej 745 USD, a które powiadomiło Komisję o zamiarze korzystania z systemu licencjonowania przymusowego w całości lub w ograniczonym zakresie jako importer. Kraje niebędące członkami WTO, a kwalifikujące się do krajów przywozu są zobowiązane do dokonania powiadomienia Komisji OECD o każdym z produktów farmaceutycznych (m.in. wskazanie jego nazwy czy potrzebnych ilości), które planuja importować, jednocześnie oświadczając o korzystaniu z systemu licencjonowania przymusowego wyłącznie w celu zaradzenia problemom dotyczacym zdrowia publicznego. Organem właściwym do udzielania licencji przymusowych w przypadkach opisanych w rozporządzeniu jest organ właściwy do udzielania licencji przymusowych na podstawie prawa krajowego, chyba że państwo członkowskie postanowi inaczej (w Polsce jest to Urząd Patentowy RP). O uzyskanie licencji przymusowej może starać się każda osoba, która złoży odpowiedni wniosek we właściwym organie, przy czym osoba zainteresowana może złożyć wnioski do organów kilku państw. Z wyłączeniem pojawienia się sytuacji krytycznej w kraju lub innych nadzwyczajnych okoliczności wymagających podjęcia pilnych działań, jak również w przypadku publicznego użycia do celów niekomercyjnych (art. 31 lit. b TRIPS), wnioskodawca (osoba zainteresowana uzyskaniem licencji przymusowej) zobowiązany jest dostarczyć organowi właściwemu przekonujących dowodów, że dołożył wcześniej wszelkich starań, aby otrzymać odpowiednie upoważnienie od uprawnionego, ale starania te nie przyniosły rezultatu w okresie trzydziestu dni przed złożeniem stosownego wniosku o udzielenie licencji przymusowej. Organ właściwy jest w takiej sytuacji zobowiązany niezwłocznie zawiadomić uprawnionego z patentu o złożonym wniosku oraz umożliwić mu zgłoszenie ewentualnych uwag i dostarczenie informacji dotyczących wniosku.

W art. 10 rozporządzenia uregulowano warunki udzielania licencji przymusowych oraz ich charakter. Licencja przymusowa, podobnie jak wynika to $\mathrm{z}$ art. 31 TRIPS, jest licencją nieprzenoszalna, z wyłączeniem przeniesienia jej wraz z przedsiębiorstwem lub częścią przedsiębiorstwa korzystającego z takiej licencji oraz licencją niewyłaczna, ograniczoną terytorialnie i czasowo. Ponadto licencja przymusowa może dotyczyć jedynie dokonywania niezbędnych działań w celu wytworzenia danego produktu farmaceutycznego na wywóz i jego dystrybucji w państwach wymienionych precyzyjnie we wniosku. Ilość wytworzonych produktów na podstawie udzielonej licencji przymusowej nie może przekraczać ilości, która jest niezbędna do zaspokojenia potrzeb państw przywozu wymienionych precyzyjnie we wniosku. Przed wysyłka produktów farmaceutycznych do państwa przywozu licencjobiorca zobligowany jest zamieścić na odpowiedniej stronie internetowej informacje dotyczace ich ilości, państw przywozu oraz cech odróżniających te produkty od innych. Wytworzone już produkty na podstawie licencji przymusowej muszą natomiast być zidentyfikowane w dokładny sposób, tj. za pomoca odpowiednich etykiet 
i oznaczeń - opakowania, ulotki i inne dokumenty uzupełniające muszą wskazywać, że produkt przeznaczony jest wyłącznie na wywóz i dystrybucję w danych państwach przywozu. Udzielenie licencji przymusowej na podstawie opisywanego rozporządzenia wiąże się również z zobowiązaniem licencjobiorcy do uiszczenia odpowiedniego wynagrodzenia uprawnionemu, ustalonego przez organ właściwy do wydania takiej licencji. Wysokość należnego wynagrodzenia ustala się co do zasady przy uwzględnieniu wartości ekonomicznej licencji na dany produkt, okoliczności humanitarnych w państwie przywozu oraz okoliczności pozahandlowych związanych z udzieleniem licencji. Za okoliczności pozahandlowe należy uznać w tym przypadku sytuację polityczną czy społeczną w państwach przywozu. Niemniej jednak w sytuacjach krytycznych lub innych nadzwyczajnych okolicznościach wymagajacych pilnych działań, a także w przypadkach publicznego użycia do celów niekomercyjnych wynagrodzenie ustala się na maksymalnie 4\% łącznej kwoty, która powinna być ostatecznie uiszczona przez licencjobiorcę. Wymienione w rozporządzeniu warunki udzielania licencji przymusowych nie naruszają innych sposobów dystrybucji produktów farmaceutycznych w państwach przywozu, co oznacza, że dystrybucja tych produktów może być prowadzona na innych zasadach handlowych i niehandlowych, w tym nieodpłatnie. W przypadku licencjonowania przymusowego na zasadach wymienionych w rozporządzeniu spełnienie opisanych warunków jest jednak niezbędne. Ich przestrzeganie może być przedmiotem kontroli organu właściwego do udzielenia takiego rodzaju licencji z urzędu lub na uzasadniony wniosek uprawnionego. Ponadto państwo członkowskie, którego organ właściwy udzielił licencji przymusowej na zasadach opisanych powyżej, powiadamia za pośrednictwem Komisji OECD Radę ds. TRIPS o takim zdarzeniu, opisując szczegółowe warunki udzielonej licencji.

Zgodnie z art. 14 rozporządzenia w przypadku negatywnego wyniku kontroli możliwe jest zajęcie lub zniszczenie produktów farmaceutycznych będących przedmiotem licencji przymusowej. Co więcej, w przypadku udowodnienia, że licencjobiorca nie przestrzega warunków licencji przymusowej, organ właściwy może wydać decyzję o jej unieważnieniu, o czym również zobowiązany jest powiadomić Radę ds. TRIPS za pośrednictwem Komisji OECD. W przypadku unieważnienia licencji przymusowej organ właściwy może wyznaczyć licencjobiorcy rozsądny termin, w którym zobowiązany jest on przekazać na swój koszt produkty będące przedmiotem licencji, a które są w jego posiadaniu lub pod jego pieczą, nadzorem czy też kontrolą do państw będących w potrzebie (państw kwalifikujących się do przywozu produktów farmaceutycznych zgodnie z rozporządzeniem) albo też zadba on o rozdysponowanie produktów w sposób ustalony przez organ właściwy w porozumieniu z uprawnionym.

W przypadku powiadomienia organu właściwego o niemożności zaspokojenia potrzeb państwa przywozu ze względu na niewystarczającą ilość produktu farmaceutycznego, możliwa jest zmiana warunków licencji przymusowej na wniosek licencjobiorcy. Organ właściwy może wówczas zezwolić na wytworzenie lub wywóz dodatkowych ilości danego produktu farmaceutycznego, które sa niezbędne do zaspokojenia potrzeb państwa przywozu. Co więcej, jeśli w państwie przywozu nie istnieje sytuacja krytyczna, inne nadzwyczajne oko- 
liczności wymagające podjęcia pilnych działań czy konieczność publicznego użycia do celów niekomercyjnych, a dodatkowa ilość produktów farmaceutycznych nie przekracza $25 \%$ ilości tych produktów przyznanej w pierwotnej licencji przymusowej, organ właściwy rozpatruje wniosek licencjobiorcy w trybie uproszczonym. Tryb uproszczony polega $\mathrm{w}$ tym przypadku na tym, że składany przez licencjobiorcę wniosek nie musi zawierać wszystkich określonych w rozporządzeniu danych, a także nie ma obowiązku przedstawiania dowodów na wcześniejszą próbę uzyskania licencji od uprawnionego, która zakończyła się niepowodzeniem.

Rozporządzenie wprowadza także zakaz przywozu do Wspólnoty produktów farmaceutycznych wytworzonych na podstawie licencji przymusowej udzielonej na warunkach w nim opisanych w celach dopuszczenia ich do swobodnego obrotu, a także zakaz ponownego wywozu tych produktów, objęcia ich procedurą zawieszająca, wprowadzania do wolnych obszarów celnych oraz składu wolnocłowego. Wyjątkiem od tych zakazów jest możliwość ponownego wywozu produktów farmaceutycznych do państw przywozu wymienionych we wniosku i wskazanych na opakowaniach oraz dokumentacji załączonej do danych produktów.

Decyzja organu właściwego o udzieleniu licencji przymusowej na warunkach opisanych w niniejszym punkcie podlega kontroli, co oznacza, że istnieje możliwość odwołania się od niej. Możliwe jest także przeprowadzenie postępowania spornego dotyczącego zgodności stanu faktycznego z warunkami licencji przymusowej - prowadzi się je zgodnie z prawem właściwym państwa, którego organ wydał decyzję o udzieleniu licencji przymusowej.

\section{Dyrektywa 98/44/WE Parlamentu Europejskiego i Rady z 6 lipca 1998 r. w sprawie ochrony prawnej wynalazków biotechnologicznych ${ }^{22}$}

Dyrektywa reguluje kwestie udzielania wzajemnych licencji przymusowych w dziedzinie wynalazków biotechnologicznych. Ustawodawca unijny nawiązał do licencjonowania przymusowego już we wstępie do wymienionej dyrektywy. Stwierdzono, że poprzez udzielanie licencji przymusowych należy za odpowiednią opłata zagwarantować możliwość wykorzystania nowych cech roślin będących wynikiem inżynierii genetycznej, w przypadku gdy w odniesieniu do danego genu czy gatunku odmiana roślin przedstawia znaczny postęp techniczny o istotnym znaczeniu gospodarczym w porównaniu z wynalazkiem zastrzeżonym w pierwotnym patencie. Ponadto nawiązano do dziedziny stosowania nowych cech roślin powstałych z nowych odmian roślin w inżynierii genetycznej. Gdy nowy wynalazek przedstawia znaczny postęp techniczny o istotnym znaczeniu gospodarczym, również należy zagwarantować dostęp do takich nowych odmian roślin poprzez udzielanie licencji przymusowych.

Do licencjonowania przymusowego bezpośrednio odnosi się art. 12 dyrektywy, dotyczący tzw. wzajemnych licencji przymusowych. Zgodnie z jego brzmie-

\footnotetext{
${ }^{22}$ Dz. Urz. UE L 213 z 30 lipca 1998 r., s. 13.
} 
niem, w przypadku gdy hodowca nie ma możliwości nabycia ani wykorzystania prawa do odmiany roślin bez naruszania wcześniejszego patentu, może on ubiegać się o udzielenie niewyłącznej licencji przymusowej na patent wcześniejszy za odpowiednią opłata. Uprawniony z patentu wcześniejszego może, w sytuacji udzielenia tego rodzaju licencji przymusowej, wnioskować o udzielenie licencji wzajemnej na korzystanie $\mathrm{z}$ chronionej odmiany na rozsądnych warunkach. Podobnie jest w przypadku wynalazków biotechnologicznych. Posiadacz patentu na dany wynalazek biotechnologiczny, który nie może go wykorzystywać bez naruszania wcześniejszego prawa do odmiany roślin, może ubiegać się o udzielenie niewyłącznej licencji przymusowej na patent wcześniejszy za odpowiednią opłata. Uprawniony z patentu wcześniejszego, podobnie jak w powyżej opisanym przypadku, może wnioskować o udzielenie mu licencji wzajemnej na korzystanie z chronionego wynalazku na rozsądnych warunkach.

Wynikiem implementacji powyższego art. 12 dyrektywy do prawa polskiego jest zawarcie w art. 82 Prawa własności przemysłowej ust. 6 dotyczącego kwestii wzajemnych licencji przymusowych. Zgodzić się jednak należy, że zawarte w nim odesłanie jedynie do art. 82 ust. 1 pkt 3 tejże ustawy jest niepełne i niefortunne. Odpowiednie stosowanie $\mathrm{w}$ tym przypadku powinny bowiem znaleźć w zasadzie wszystkie przepisy regulujące instytucję licencji przymusowej w przywołanej ustawie ${ }^{23}$.

\section{POZOSTALE AKTY PRAWNE}

Istnieja takie akty prawne, które jedynie nadmieniają instytucję licencji przymusowej, nie regulując jej w żaden sposób.

Zgodnie z Konwencja o udzielaniu patentów europejskich z 5 października 1973 r. ${ }^{24}$ uzyskanie licencji przymusowej na patent europejski następuje zgodnie z procedurami krajowymi, w którym zainteresowany stara się o uzyskanie takiej licencji. Regulamin wykonawczy do konwencji stanowi zaś, że licencja przymusowa to licencja ex officio, która daje prawo do korzystania z opatentowanych wynalazków jedynie w interesie publicznym. Zasada ta dotyczy jednakże tylko materiału biologicznego.

Podobnie w rozporządzeniu Parlamentu Europejskiego i Rady (UE) nr 1257/2012 z 17 grudnia 2012 r. wprowadzającym wzmocnioną współpracę w dziedzinie tworzenia jednolitego systemu ochrony patentowej ${ }^{25}$ licencje przymusowe na patenty europejskie o jednolitym skutku podlegają ustawodawstwu państw członkowskich.

${ }^{23}$ Tak w: P. Kostański, Komentarz do art. 82 Prawa własności przemysłowej, w: idem (red.), Prawo własności przemysłowej. Komentarz, Warszawa 2014, s. 569; M. du Vall, Prawo patentowe, Warszawa 2008, s. 393; E. Nowińska, U. Promińska, K. Szczepanowska-Kozłowska, Wtasność przemysłowa $i$ jej ochrona, Warszawa 2014, s. 108.

${ }^{24}$ Dz. U. 2004, Nr 79, poz. 737 wraz z Aktem rewidujacym (Dz. U. 2007, Nr 236, poz. 1736).

25 Dz. Urz. UE L 361 z 31 grudnia 2012 r., s. 1. 
Na końcu zauważyć należy, że przedstawiciele organów Unii Europejskiej wiedza, jak delikatną i trudną sprawa jest system licencjonowania przymusowego, który z samego założenia narażony jest na wiele nadużyć. Z tego względu Parlament Europejski wydał 9 czerwca 2015 r. rezolucję w sprawie strategii na rzecz ochrony i egzekwowania praw własności intelektualnej w państwach trzecich ${ }^{26}$. Parlament zauważył m.in., że konkurencyjność UE opiera się i w coraz większym stopniu opierać się będzie na kreatywności i innowacji, a ich ochrona ma zasadnicze znaczenie dla konkurencyjności Europy. Niemniej jednak, pomimo konieczności ochrony interesów i konkurencyjności szczególnie unijnych firm farmaceutycznych poprzez zachowanie ich potencjału innowacyjnego, niezbędne jest wsparcie korzystania z form elastyczności przewidzianych w porozumieniu TRIPS i uznanych w tzw. deklaracji dauhańskiej. Wszelkie formy elastyczności powinny być oczywiście w pełni zgodne z zasadą niedyskryminacyjnego traktowania wszystkich dziedzin technologii (art. 27 ust. 1 TRIPS), jednakże państwa członkowskie UE powinny wspierać konstruktywny dialog z udziałem wszystkich zainteresowanych stron na temat dostępu do leków oraz do wskazania rozwiązań ułatwiających taki dostęp ludności najbiedniejszych państw, która nie posiada środków pozwalających na efektywne korzystanie ze skutecznych, najlepszych metod leczenia. Jednym z takich rozwiązań jest właśnie system licencjonowania przymusowego.

\section{ZAKOŃCZENIE}

Zadaniem systemu licencjonowania przymusowego jest przeciwdziałanie nierównościom konkurencyjności rynków państw. Ma on pomagać przede wszystkim państwom słabo rozwiniętym i rozwijającym się. Warunki udzielania licencji przymusowych sa zatem dokładnie opisane w aktach prawnych, które dotyczą tej problematyki. Co do zasady, ustawodawcy krajowi równie dokładnie wymieniaja przesłanki udzielania licencji przymusowych, tak aby przypadki tego rodzaju licencjonowania miały miejsce jedynie w wyjatkowych przypadkach, jak np. zagrożenie dla stanu bezpieczeństwa narodowego czy nadużywanie patentu przez uprawnionego. Przedmiotem licencji przymusowych sa zatem patenty dotyczące rozwiązań ważnych z punktu widzenia państwa czy jego ludności, jak np. produkty farmaceutyczne. Odpowiednie organizacje międzynarodowe podkreślaja jak ważne jest odpowiedzialne podejście do systemu licencjonowania przymusowego - państwa powinny w każdym przypadku działać w dobrej wierze, nie starając się realizować celów wyznaczonej przez siebie polityki przemysłowej lub handlowej.

System licencjonowania przymusowego ma być także środkiem zaradczym na patologiczne mechanizmy obecne na konkretnych rynkach, szczególnie w branży farmaceutycznej. Przykładem takiego mechanizmu może być decyzja z 2015 r. o podwyższeniu przez właściciela leku (patentu) ceny leku

${ }^{26}$ Tekst rezolucji dostępny na: http://www.europarl.europa.eu/sides/getDoc.do?pubRef=-// EP//TEXT+TA+P8-TA-2015-0219+0+DOC+XML+V0//PL [dostęp: 10.12.2016]. 
Daraprim (lek stosowany w leczeniu AIDS oraz po przeszczepach) z 13,50 do 750 USD za pigułkę czy też podobna decyzja z $2007 \mathrm{r}$. o podwyższeniu ceny leku Acthar Gel (lek stosowany w leczeniu ataków padaczki u niemowląt) z 50 do 28000 USD za fiolkę ${ }^{27}$. Choć sa to dość kontrowersyjne przypadki, gdyż spółki farmaceutyczne (podobnie jak każdy inny podmiot obecny na rynku) mogą w sposób dowolny ustalać ceny oferowanych leków, stanowią one przykład nadużywania prawa do patentu. W przypadku gdy mamy do czynienia z produktem ratującym życie, nie tylko lekiem, nie powinna budzić wątpliwości konieczność istnienia granicy wolności rynkowej.

Powyższe stwierdzenie brzmi nie tylko niezwykle i obiecująco, ale również życzeniowo oraz niewiarygodnie. Uzyskanie licencji przymusowej nie jest wcale łatwe. Stanowi to długi, mozolny i często kosztowny proces. Co więcej, producentów z większości państw słabo rozwiniętych nie tylko nie stać na wytworzenie produktów będących przedmiotem licencji przymusowej, ale często nie posiadaja samych mocy produkcyjnych - specjalistów, odpowiednich fabryk i magazynów czy sprzętu. Przypadki udzielania licencji przymusowych zdarzają się niezmiernie rzadko również dlatego, że w społeczeństwach kapitalistycznych jakakolwiek próba ingerencji w prawa osoby uprawnionej spotyka się najczęściej z krytyką i wzbudza kontrowersje wśród wielu środowisk. Nie da się ukryć, że licencjonowanie przymusowe nie leży w interesie dużych spółek. Przeznacza się w nich ogromne pieniądze na badania i analizy, chcąc odpowiednio zarobić na ich wynikach. Z tego właśnie powodu tak ważne jest poszukiwanie zrównoważonego środka, który nie zniechęcałby do przeznaczania pieniędzy na przeprowadzanie odpowiednich badań mających na celu uzyskiwanie nowych, lepszych, bardziej skutecznych metod i produktów, a który jednocześnie gwarantowałby możliwość korzystania z tych najlepszych rozwiązań także potrzebującym.

mgr Anna Miszczak

amiszczak@miszczak.biz

\section{COMPULSORY LICENSING UNDER EUROPEAN UNION LAW AND INTERNATIONAL TREATIES BINDING THE REPUBLIC OF POLAND}

Summary

This article describes EU legislative acts and international treaties agreements that are binding on the Republic of Poland and concern compulsory licensing. Compulsory licensing means that in certain specific circumstances specified by law, a competent authority may grant a licence for a patent without the consent of the patent holder. The extent, time scope, fee for the patent holder and other conditions of a compulsory license are specified by the competent authority in the course of relevant proceedings. Although the characteristic feature of Intellectual Property law is the principle of territoriality, all legislative acts referred to in the article provide for the conditions which each state must observe when it decides to regulate this kind of licensing in its own legal system. One of the main goals of the acts described in the article is to create such a system of compulsory licensing that would be consistent and unified. The reasons why compulsory licences are granted very rarely are also given.

${ }_{27}$ M. Herper, Martin Shkreli - wróg publiczny numer 1, „Forbes” 2016, nr 3, s. 112. 